\title{
IMPROVEMENT OF ANAEROBIC DIGESTION OF RICE STRAW USING WET - MILLING PRETREATMENT APPROACH
}

\author{
NAGHAM ELSAIDY $^{1}$; FATMA ABOUELENIEN ${ }^{1}$ and YUTAKA NAKASHIMADA ${ }^{2}$ \\ ${ }^{1}$ Department of Hygiene and Preventive Medicine, Faculty of Vet. Med., Kafr Elshiekh University, Kafr Elshiekh \\ Governorate-33156, Egypt. \\ ${ }^{2}$ Department of Molecular Biotechnology, Graduate School of Advanced Sciences of Matter, Hiroshima University, \\ Kagamiyama 1-3-1, Higashi- Hiroshima
}

Received 22 December 2015; Accepted 20 January 2016

\begin{abstract}
As rice production continues to rise in order to provide a stable food source for over half of the world's population, so rice straw will continue to be an abundant and accessible agricultural waste. Rice straw is a widely available lignocellulosic waste with potential for energy recovery through anaerobic digestion. Lignin slows the hydrolysis phase, resulting in low methane recovery and long digestion periods. Pretreatment with wet milling was tested in contrast with grinding rice straw and control one without rice straw, as a technique for enhancing the anaerobic digestion. Two mixtures were used, M1 containing grinded rice straw and M2 containing wet milled rice straw and the both were inoculated with seed sludge and kept under thermophilic conditions $\left(55^{\circ} \mathrm{C}\right)$ with dry fermentation (total solids, TS\%) over 20 . Control vials were used with only seed sludge. Two batch cultures lasted for 35 days for each. The results showed that wet milling seems to enhance methane production from rice straw with maximum production of $1493.98 \mathrm{ml} / \mathrm{g}$-vs compared with $387.7 \mathrm{ml} / \mathrm{g}$ vs from grinded one. Methane percentage was ranged from 48 to $55 \%$. Acetate production was low ranged from 0.74 to $0.93 \mathrm{mM} / \mathrm{kg}$ mixture which meant success of methane production. Thermophilic condition was used at $55^{\circ} \mathrm{C}$ which in contrast to previous study enhance the degradation. Methane potential from grinded rice straw, wet milled rice straw, and glucose as reference was 234,230 , and $338 \mathrm{l} / \mathrm{kg}$ vs respectively.
\end{abstract}

Keywords: Dry anaerobic-digestion, Methane production, Rice straw, Wet-Milling, Pretreatment, Thermophilic.

\section{INTRODUCTION}

Rice is the most important staple food consumed daily by at least half of the world's population, including all Asian countries, most of West and North Africa, some countries in East and Central Africa (Sreepada and Vijayalaxmi, 2013). The Food and Agriculture Organization of the United Nations (FAO) estimated that a total of 679 million tons of rice were produced in 2009 (FAOSTAT, 2011), which equates to approximately 916 million tons of rice straw available for energy production (Kadam et al., 2000).

Egypt has a large rural population whose major energy source was biofuel (crop residue and fuel wood). However, rapid economic development has increased rural access to commercial energy, and the use of biofuel is decreasing. As a result, crop residue is not in such high demand as fuel, so it is increasingly burned in the crop fields (El Saidy, 2011).

Corresponding author: Dr. Nagham Elsaidy

E-mail address: nagham.elsaidy@yahoo.com

Present address: Department of Hygiene and Preventive Medicine,

Faculty of Vet Med., Kafr Elshiekh University, Kafr Elshiekh Governorate-33156, Egypt.
The issue that contributed to formation of smoke cloud over Egypt that always in parallel to the period of rice straw burning by farmers in the delta Governorates especially Dakahlya, Sharkia, and Kalyobia (Moussa and Abdelkhalek 2007) in a phenomenon called (Black cloud). Akmal et al. (2011) estimated the amount of rice straw produced annually in Egypt by 3.5 million tons.

A major problem with burning of rice straw in the fields is the incomplete combustion of the burning nature which result in emission of large amounts of smoke and other pollutants into the atmosphere, including toxic gases $\left(\mathrm{Co}_{2}\right.$, carbon monoxide $(\mathrm{CO})$, volatile organic compound (VOC), fine/inhalable particles and carcinogenic polycyclic aromatic hydrocarbons as recorded by (Kim Oanh et al., 2005), which accelerates increase in atmospheric temperature and can cause global warming. In addition to their effects on ambient air hygiene it poses a public health hazard as the smoke from biomass burning has been shown to be potentially toxic (Kim Oanh et al., 2002). Due to health and environmental concerns, many countries have imposed new regulations restricting field burning activities (Mansaray et al., 1999). Therefore, there 
were a lot of trials suggested several alternatives methods of rice straw uses instead of its burning. Van Nguu (2000) mentioned that the most traditional uses of rice byproducts includes straw and hull were used for energy, animal feed, building materials and paper production. Mansour et al. (2007) suggested recycling of rice straw with a mixture of cement not only forms a sustainable low cost building material, but could also reduce air pollution. In addition to these benefits, the straw could act as a thermal insulation material for the unpleasant Egyptian weather. Another potential use of rice biomass for energy production can be utilized worldwide; even in the developing countries is the conversion of rice residues into the clean-burning fuel through anaerobic digestion. The issue which represents an important trend for Egypt, in the present time where Egypt is facing a high population growth rate, rising fuel costs and much need for clean fuel sources for generation of heat and /or electricity. During the anaerobic digestion process, microorganisms convert biomass into biogas, a mixture of methane and carbon dioxide with trace amount of other gases like carbon monoxide and hydrogen, in the absence of oxygen (Ondrej and Dagmar, 2013). The produced biogas can be used as fuel to generate heat and/or electricity. Furthermore, the digestate can be used as a good organic fertilizer (Chandra et al., 2012). The most important challenges and limitations in the process of converting urice straw to biogas are mainly related with high Carbon/Nitrogen $(\mathrm{C} / \mathrm{N})$ ratio or low hydrolysis performance and digestibility because of high lignin content and its complex, stable and recalcitrant lignocellulosic structure (Chen and Lei, 2008). Therefore, it needs a further balance of nutrients and destructive pretreatments. Pretreatment is a key process for accomplishing efficient enzymatic hydrolysis of lignocellulosic biomass, and it has been subject of many studies (Sun and Cheng, 2002; Mosier et al., 2005; Alvira et al., 2010). Among the pretreatment methods used wet milling method is described as an energy saving pretreatment method (Endo et al., 2008 and Hideno et al., 2009). The advantages of this pretreatment method were include its environmental-friendly nature given only water that used as a carrier; it is effective for enzymatic hydrolysis, and has a low energy consumption compared with conventional ball milling (Hideno et al., 2009; Yanagida et al., 2009). As little research has been conducted to examine the effect of direct biogasification of rice straw under anaerobic condition which is still important and promising, especially in rural areas of developing countries. So the objective of this study was to assess the availability of direct anaerobic digestion of rice straw with anaerobic sludge, and to examine the effect of wet milling pretreatment on methane yield and biogasification characteristics of rice straw during semi-continuous batch culture under thermophilic condition.

\section{MATERIALS AND METHODS}

\section{Seed sludge}

The seed thermophilic methanogenic sludge used in the study was collected from a wastewater treatment center in Hiroshima, Japan. The digested excess sludge referred to as sludge in this article is a digested sludge obtained after the fermentation of methane by thermophilic anaerobic digestion of excess activated sludge (Nishio and Nakashimada, 2007). This sludge was anaerobically incubated at $55^{\circ} \mathrm{C}$ for 60 days in the laboratory to achieve complete consumption of the substrate, in order to be used as inoculum or seed sludge. The sludge was stored at the refrigerator with $-4^{\circ} \mathrm{C}$ before use and its Characteristics were summarized in Table 1.

\section{Biomass used in the study \\ 2.1 Rice straw}

Rice straw used in this study was collected from field at Fukushima prefecture; in Japan in 2013. The air dried rice straw was cut into small pieces and further milled to powder, by grinding with a hammer mill and fraction passed $250 \mu \mathrm{m}$ mesh. Its Characteristics were summarized in Table 1.

\subsection{Treated Rice straw}

Rice straw was treated with a wet-milling method, using a bead mill with 4L of volume (LME4, Tsukuba, Japan), to accelerate methane production that was developed by Ohtuka and Nakamura in Forestry and Forest Products Research Institute, Japan (Hideno et al., 2009). Its character was summarized in Table 1.

\section{Batch Experimental design \\ 3.1 First batch}

\section{1.a Mixture 1 (M1) using Grinded rice straw}

Mixture 1 (M1) was used to measure methane production from grinded rice straw, $80 \mathrm{~g}$ of the seed sludge was mixed with $4 \mathrm{~g}$ rice straw, $1 \mathrm{~g}$ NaHCO3 and $16 \mathrm{~g}$ Milli $\mathrm{Q}$ water. The mixture was filled into $700 \mathrm{ml}$ anaerobic vials. The headspace of the bottle was filled with nitrogen gas to achieve anaerobic condition and the anaerobic vials were statically set at the incubator with $55^{\circ} \mathrm{C}$. Simultaneously, the control culture without rice straw was also carried out. The triplicate culture was performed for each experiment. The character, conditions, ratios and experimental setup of M1 are illustrated in table 2. TS and VS of M1 content were illustrated in table 3. (Abouelenien et al., 2010).

\section{1.b Mixture 2 (M2) using treated rice straw}

Mixture 2 (M2) was used to measure methane production from rice straw treated with wet-milling method, $80 \mathrm{~g}$ of the seed sludge was mixed with $20 \mathrm{~g}$ treated rice straw and $1 \mathrm{~g} \mathrm{NaHCO}_{3}$. The mixture was filled into $700 \mathrm{ml}$ anaerobic vials. The headspace of the bottle was filled with nitrogen gas to achieve anaerobic condition and the bottle was statically set at 
the incubator with $55^{\circ} \mathrm{C}$. Simultaneously, the control culture without rice straw was also carried out. The triplicate cultures were performed for each experiment. The characters, conditions, ratios and experimental setup of M2 were illustrated in table 2 . TS $\%$ and VS\% of M2 content were illustrated in table 3. (Abouelenien et al., 2010).

\subsection{2nd batch}

\section{2.a Mixture 1 (M1) using Grinded rice straw}

At the end of first batch which was reached when gas production stopped, the anaerobic vials were opened and $20 \mathrm{~g}$ of the first batch M1 was mixed with $1 \mathrm{~g}$ grinded rice straw and $4 \mathrm{ml}$ Milli-Q water. The mixture was filled into $500 \mathrm{ml}$ anaerobic vials of total volume. The headspace of the bottle was filled with nitrogen gas to achieve anaerobic condition and the bottle was statically set at the incubator with $55^{\circ} \mathrm{C}$. Simultaneously, the control culture without rice straw was also carried out. The triplicate cultures were performed for each experiment (Abouelenien et al., 2009).

\section{2.b Mixture 2 (M2) using treated rice straw}

At the end of the first batch which reached when gas production stopped, the anaerobic vials were opened and $20 \mathrm{~g}$ of the first batch M2 was mixed with, $5 \mathrm{~g}$ pretreated rice straw.

The mixture was filled into the bottle with $500 \mathrm{ml}$ of total volume. The headspace of the bottle was filled with nitrogen gas to achieve anaerobic condition and the bottle was statically set at the incubator with $55^{\circ} \mathrm{C}$. Simultaneously, the control culture without rice straw was also carried out. The triplicate culture was performed for each experiment. (Abouelenien et al., 2009).

\section{Analytical methods}

Fermentation samples (ca. $0.3 \mathrm{~g}$ wet weight) were withdrawn into 2-ml plastic tubes and suspended with $1.2 \mathrm{ml}$ deionized water. The suspension was centrifuged at 3,000 rpm for $10 \mathrm{~min}$ at $4{ }^{\circ} \mathrm{C}$, and the clear supernatant was used for measurement of VFAs. VFAs were measured using High Performance Liquid Chromatograph (Shimadzu, Kyoto, Japan) that was equipped with Aminex HPX-87H Column, 300mm x $7.8 \mathrm{~mm}$ (Bio-Rad, Tokyo, Japan). The column temperature was $65^{\circ} \mathrm{C}$. The flow rate was $0.8 \mathrm{ml} \mathrm{min}$ ${ }^{-1}$ for $0.005 \mathrm{M} \mathrm{H}_{2} \mathrm{SO}_{4}$ solution, used as a mobile phase. Total solids (TS) and Volatile solid (VS), were measured in accordance with the standard methods (APHA, 1998). To measure total solids in the organic matter, the sample was put on the glass filter (GS-25. ADVANTEC, $47 \mathrm{~mm}$ ) and dried more than $24 \mathrm{~h}$ at $80^{\circ} \mathrm{C}$ and weighted. Then, the dried sample was treated at $600 \mathrm{oC}$ for $3 \mathrm{~h}$, and then weighted to measure volatile solids (APHA, 1998).

Gas production was measured periodically by displacement of saturated aqueous $\mathrm{NaCl}$ in a graduated cylinder. The compositions of $\mathrm{CH}_{4}, \mathrm{H}_{2}$, and $\mathrm{CO}_{2}$ were determined by a gas chromatograph (GC$8 \mathrm{~A}$, Shimadzu) with a thermal conductivity detector equipped with a glass column $(2 \mathrm{~m} \times 3 \mathrm{~mm})$ packed with unibeads C $60 / 80$ (Shimadzu) at $140^{\circ} \mathrm{C}$. Argon was used as the carrier gas at a pressure of $100 \mathrm{kPa}$. (APHA, 1998).

\section{Calculation of methane potential}

Methane production was calculated as the volume of methane produced per unit weight of straw TS or VS loaded. The cumulative methane production by the stems and leaves of each variety was fitted with the modified Gompertz equation using the solver function in Microsoft Excel:

$M=P \times \exp \left\{-\exp \left[\frac{\operatorname{Rm} \times e}{p}(\lambda-t)+1\right]\right\} .($ Feng et al., 2013)

Where $\mathrm{M}$ is the cumulative methane production $(\mathrm{ml})$, $\mathrm{t}$ is the incubation time (days), $\lambda$ is the lag phase (days), $\mathrm{P}$ is the methane production potential $(\mathrm{ml}), \mathrm{R}_{\mathrm{m}}$ is the methane production rate $(\mathrm{ml} / \mathrm{d})$ and $e$ is the exponential index.

\section{RESULTS}

The substrate characterization, composition, and concentrations in grinded rice straw, wet-milled rice straw and seed sludge, were shown in Tables 1 and 3. On a dry matter (TS) basis, wet milled rice straw contained higher VS than Grinded rice straw and seed sludge; the VS \% content of wet milled rice straw was $87 \%$, compared to that of grinded rice straw that was $85 \%$.

The course of daily biogas production was illustrated in Fig. 1 with peak of production observed in the $3^{\text {rd }}$ day of first batch for all treatments. With highest amount obtained from Wet-milled pretreated rice straw (M2), $240 \mathrm{ml} / \mathrm{g}-\mathrm{VS} / \mathrm{d}$ followed by grinded (M1), $132.2 \mathrm{ml} / \mathrm{g}-\mathrm{VS} / \mathrm{d}$, and finally control $(59.9 \mathrm{ml} / \mathrm{g}$ $\mathrm{VS} / \mathrm{d}$ ). While in the $2^{\text {nd }}$ batch there were two peaks of biogas production from both M1 and M2, the first peak observed in $1^{\text {st }}$ day, (the $36^{\text {th }}$ day of the total course), with 161,5 and $899.47 \mathrm{ml} / \mathrm{g}$-vs/day from M1 and $\mathrm{M} 2$ respectively. The $2^{\text {nd }}$ peak was reached at $12^{\text {th }}$ $\mathrm{d}\left(48^{\text {th }}\right.$ day of the total course) with 228 and 806 $\mathrm{ml} / \mathrm{g}-\mathrm{vs} / \mathrm{d}$ from M1 and M2 respectively. Additionally it was observed that in the 2 batches gas production was higher in the beginning of each batch and then decreased toward the end of the batch with higher biogas yield in the $2^{\text {nd }}$ batch than the first.

The results of cumulative biogas yield were illustrated in Fig. 2a for Grinded, pretreated and control, the highest amount was obtained from M2 in both $1^{\text {st }}$ and $2^{\text {nd }}$ batches, with values of 860 and 3267 $\mathrm{ml} / \mathrm{g}$-vs respectively. 
The methane content was measured every day, and the average methane content in each group was 55.4, $48 \%$ and $24 \%$ for M2, M1 and control respectively. The other components of biogas were Carbon dioxide, Hydrogen and Nitrogen. Fig2.b illustrated the cumulative methane production from all mixtures during $1^{\text {st }}$ and $2^{\text {nd }}$ batches under thermophilic $\left(55 \mathrm{C}^{\circ}\right)$ conditions. Highest cumulative methane was obtained at the end of the $2^{\text {nd }}$ batch from M2 (1493.98 ml/g-vs), with about 4 times as that obtained from M1 (387.7 $\mathrm{ml} / \mathrm{g}$-vs).

The changes in water content, total solid percentage (TS \%) and Volatile solid percentage (VS\%) during Anaerobic Digestion of rice Straw from M1 and M2 in initial and final of $1^{\text {st }}$ and $2^{\text {nd }}$ batch were illustrated in table 5. TS\% was decreased from 20.9 to $20 \%$ and from 18.9 to $16.3 \%$ in initial and final of $1^{\text {st }}$ and $2^{\text {nd }}$ batches of M1, and from 20.4 to $19.7 \%$ and from 19.5 to $19.2 \%$ in initial and final of $1^{\text {st }}$ and $2^{\text {nd }}$ batch of M2 respectively. On the other hand VS\% was decreased from 65 to $57.73 \%$ and from 77.8 to $67.17 \%$ of M1 $1^{\text {st }}$ and $2^{\text {nd }}$ batch respectively, and from 66.9 to $64.3 \%$ of M2 $1^{\text {st }}$ and $2^{\text {nd }}$ batch respectively.

Table. 6 illustrated the potential methane production from grinded, wet milled, and glucose as reference was 234,230 , and 338 1/kg vs respectively.

\section{Figures caption}

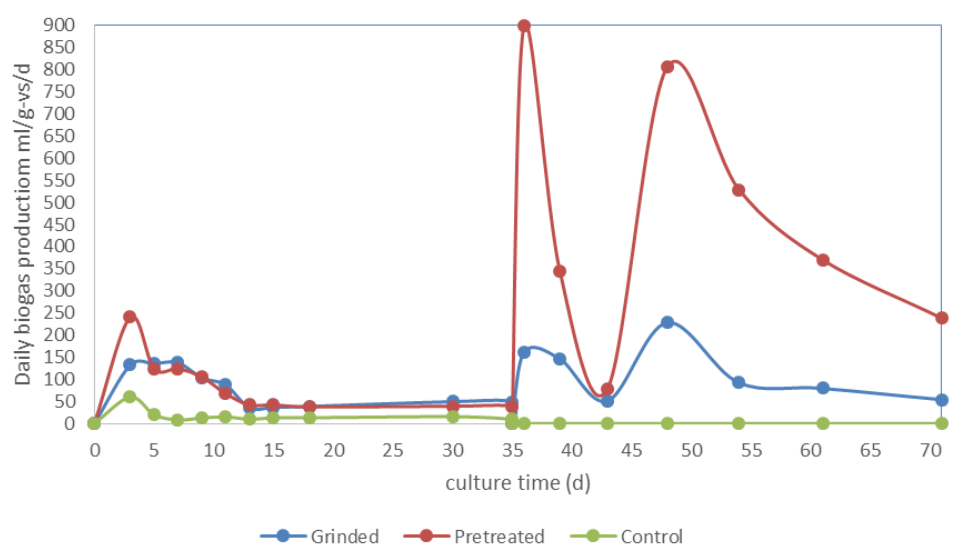

Fig. 1: Daily biogas production from dry anaerobic digestion by repeated batch culture of M1 Containing Grinded rice straw or M2 containing pretreated rice straw (by wet milling). Seed sludge was used as inoculum. Fermentation temperatures were $55{ }^{\circ} \mathrm{C}$ (thermophilic). Duration of batch I was 35 days; batch II was 35 days (fixed culture time).

Fig. 2a

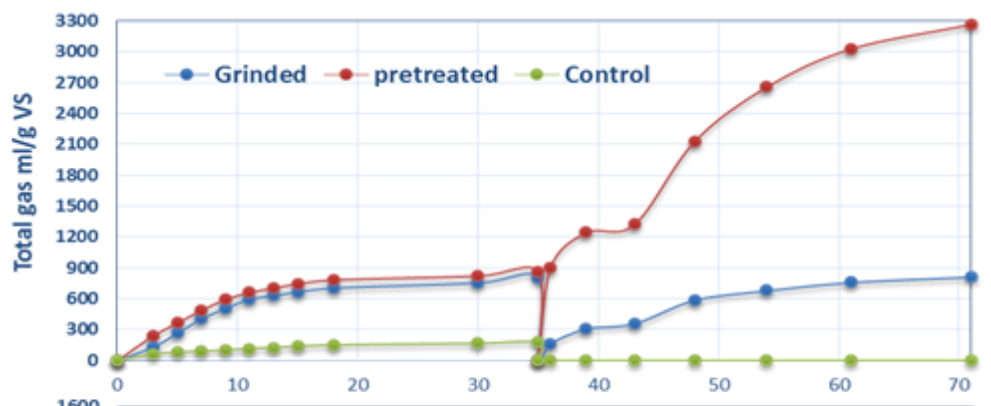

Fig. $2 b$

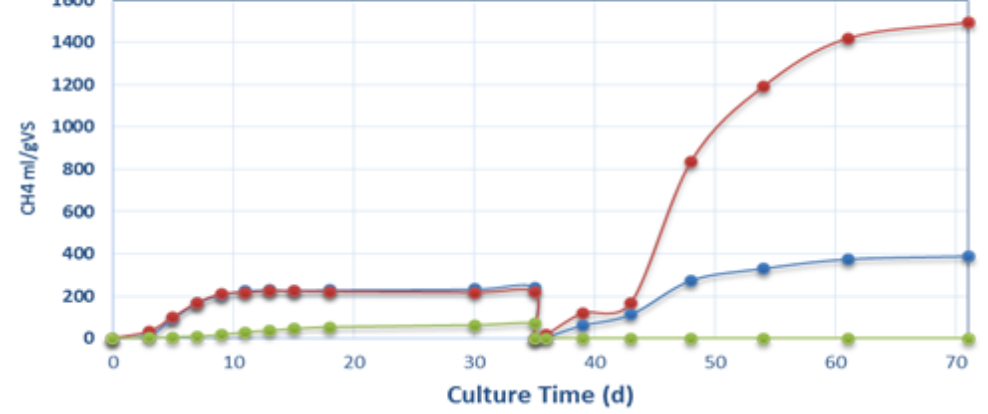

Fig. 2 (a,b): Cumulative biogas and Methane production from dry anaerobic digestion by repeated batch culture of M1 Containing Grinded rice straw or M2 containing pretreated rice straw (by wet milling). Seed sludge was used as inoculum. Fermentation temperature was $55^{\circ} \mathrm{C}$ (thermophilic). Duration of batch I was 35 days; batch II was 35 days (fixed culture time). 
Table 1: Characteristic of rice straw and seed sludge used in the present study.

\begin{tabular}{cccc}
\hline Parameter & Rice straw & $\begin{array}{c}\text { Rice straw treated } \\
\text { with a wet-mill }\end{array}$ & Seed sludge \\
\hline Total Solids, \% (w/w) & 98.3 & 82.7 & 78.5 \\
\hline Volatile Solids, $(\mathrm{g} / \mathrm{g}-\mathrm{TS})$ & 0.85 & 0.87 & 0.857 \\
\hline
\end{tabular}

Table 2: Rice straw pretreatment conditions and Experimental setup that used in the present study.

\begin{tabular}{cccc}
\hline Mixture & Pretreatment condition & seed sludge: Rice straw (volume basis) & $\begin{array}{c}\text { Temperature } \\
(\mathrm{C})\end{array}$ \\
\hline M1 & Grinded alone & $4: 1$ & 55 \\
\hline M2 & Wet milling & $4: 1$ & 55 \\
\hline Control & - & $1: 0$ & 55 \\
\hline
\end{tabular}

M1: Mixture was used to measure methane production from grinded rice straw.

M2: Mixture was used to measure methane production from rice straw treated with wet-milling method.

Table 3: Feed substrate characteristics in the present study.

\begin{tabular}{cccc}
\hline Mixture & Pretreatment condition & TS\% & VS\% of TS \\
\hline M1 & Grinded alone & 20.9 & 65.01 \\
\hline M2 & Wet milling & 20.4 & $64 \%$ \\
\hline Control & - & 17.45 & 60.6 \\
\hline
\end{tabular}

M1: Mixture was used to measure methane production from grinded rice straw.

M2: Mixture was used to measure methane production from rice straw treated with wet-milling method.

TS \%: Total solids \%

VS\%: Volatile solids \%

Table 4: Methane Yields (in terms of VS) from Anaerobic Digestion of Rice Straw

\begin{tabular}{|c|c|c|c|c|}
\hline $\begin{array}{c}\text { Methane Yield } \\
\text { (L/Kg VS added) }\end{array}$ & Type of pretreatment & $\begin{array}{l}\text { Digestion } \\
\text { Temp }\left({ }^{\circ} \mathrm{C}\right) \\
\end{array}$ & $\begin{array}{c}\text { Time period } \\
(\mathrm{d})\end{array}$ & References \\
\hline 46 & Cut $(1 \mathrm{~cm})$ & 35 & 92 & Mussoline et al. (2013) \\
\hline 231 & Codigestion with pig waste water & 35 & 189 & Mussoline et al. (2012) \\
\hline $302-340$ & $\begin{array}{l}\text { Cut }(1 \mathrm{~cm}), \text { Codigestion with pig } \\
\text { waste water \& paper Mill Sludge }\end{array}$ & 35 & 92 & Mussoline et al. (2013) \\
\hline 195 & Cut $(50-100 \mathrm{~mm})$ & 40 & 40 & Dinuccia et al. 2010 \\
\hline 280 & Cut (3-5) & 22 & 120 & Lei et al. 2010 \\
\hline 215 & Pulverized & 35 & 120 & El-shinnawi et al. 1989 \\
\hline 190 & $2 \% \mathrm{NH} 3$ & 35 & 24 & Zhang and zhang 1999 \\
\hline 198 & Cut $(25 \mathrm{~mm})+2 \% \mathrm{NH} 3$ & 35 & 24 & Zhang and zhang 1999 \\
\hline 245 & $\begin{array}{c}\text { Ground }(25 \mathrm{~mm}), 2 \% \mathrm{NH} 3, \\
\text { preheated to } 110 \mathrm{C}\end{array}$ & 35 & 24 & Zhang and zhang 1999 \\
\hline 273 & $\begin{array}{l}\text { Cut/ pre-digested with biogas } \\
\text { sludge for } 46 \mathrm{hrs}\end{array}$ & $26-28$ & 146 & Sun et al. 1987 \\
\hline $224^{\#}$ & Cut/ delignified & 30 & 63 & Ghosh (1999) \\
\hline $328^{\#}$ & Cut/ delignified/white rot fungi & 30 & 63 & Ghosh (1999) \\
\hline $296^{\#}$ & Cut/ delignified/brown rot fungi & 30 & 63 & Ghosh (1999) \\
\hline 240 & Cut/ white rot fungi & $\begin{array}{c}18-28 \\
\text { (Ambient) } \\
\end{array}$ & 89 & Lianhua et al. (2010) \\
\hline 93 & Milled/white rot fungi & 25 & 59 & Lianhua et al. (2010) \\
\hline 124 & Milled/white rot fungi & 35 & 59 & Lianhua et al. (2010) \\
\hline 388 & Grinded Rice straw & 55 & 71 & Current study \\
\hline 1494 & Wet milling Rice straw & 55 & 71 & Current study \\
\hline
\end{tabular}

VS\%: Volatile solids \% 
Table 5: Changes in water content, TS\% and VS\% and during anaerobic digestion of rice straw with different experimental conditions.

\begin{tabular}{ccccccccc}
\hline & \multicolumn{3}{c}{ Grinded rice straw } & \multicolumn{4}{c}{ Wet milling } \\
\hline & \multicolumn{2}{c}{$\boldsymbol{1}^{\text {st }}$ batch } & \multicolumn{2}{c}{ 2 nd batch } & \multicolumn{2}{c}{$\mathbf{1}^{\text {st }}$ batch } & \multicolumn{2}{c}{$\mathbf{2}^{\text {nd }}$ batch } \\
\hline & Initial & final & Initial & final & Initial & final & Initial & final \\
\hline $\begin{array}{c}\text { Water } \\
\text { content }\end{array}$ & 79.1 & 79.97 & 81.07 & 83.7 & 79.6 & 80.3 & 80.5 & 80.8 \\
\hline TS\% & 20.9 & 20.03 & 18.93 & 16.3 & 20.4 & 19.7 & 19.2 & 19.5 \\
\hline VS\% & 65.01 & 57.73 & 67.17 & 77.8 & 64 & 59 & 66.9 & 64.27 \\
\hline
\end{tabular}

TS \%: Total solids \%

VS\%: Volatile solids \%

Table 6: Properties of methane production of tested biomass.

\begin{tabular}{lccc}
\hline Biomass & $\begin{array}{c}\text { Methane potential } \\
(\mathrm{ml} / \mathrm{g}-\mathrm{VS})\end{array}$ & $\begin{array}{c}\text { production rate } \\
(\mathrm{ml} / \mathrm{g}-\mathrm{VS} / \mathrm{d})\end{array}$ & $\begin{array}{c}\text { Delay time } \\
(\mathrm{d})\end{array}$ \\
\hline Grinded rice straw & 234 & 44 & 2.8 \\
\hline Grinded rice straw with wet-milling & 230 & 38 & 2.2 \\
\hline Glucose (as a reference) & 338 & 40.4 & 3.6 \\
\hline
\end{tabular}

VS\%: Volatile solids \%

\section{DISCUSSION}

Two semi continuous batch cultures were conducted to evaluate the process of anaerobic digestion of rice straw. The whole duration of biogas production lasted 35 days for each batch. The biogas production increased rapidly in the initial time and then decreased by the end of each batch in all mixtures. The methane percentages $(55.4,48 \%$ and $24 \%$ for M2, M1 and control respectively) were lower than that obtained by Abouelenien et al. (2010) and Magbanua et al. (2001). As protein rich substrates such as Poultry manure, hog wastes and sewage sludge produced higher methane percentage than that obtained from carbohydrate as the main component of rice straw is complex carbohydrate in the form of cellulose, hemicellulose and lignin (Angelidaki and Sanders 2004).

The rice straw as a substrate with high lignin content, inappropriate $\mathrm{C} / \mathrm{N}$ ratio, and high total solids content can be easily anaerobically digested only when it is pretreated (Cundr and Haladová; 2014). Wet milled pretreated rice straw (M2) showed highest biogas and methane yield if compared with control and grinded rice straw (M1), this could be explained as follow; rice straw is a lignocellulose containing primary cellulose and hemi-cellulose which is difficult to degrade using conventional anaerobic digestion processes. The degradation of lignocelluloses into biogas is a complicated process, since lignocelluloses have a recalcitrant structure which is naturally designed to prevent enzymatic degradation (Demirel and Scherer; 2011 and Niu et al., 2013). Lignocellulose formed in a compact and crystalline structure and often contain a high amount of lignin. In order to permit degradation of these materials in an anaerobic digester, the structure has to open up and/or the lignin has to be degraded or removed. Pretreatment of rice straw by mechanical size reduction and/or wet milling improves its digestion (Zhang and Zhang, 1999; Sun and Cheng, 2002; Mosier et al., 2005 and Alvira et al., 2010). In the current study the produced methane was much higher than that produced from previous work as illustrated in table 4.

Anaerobic digestion was performed under dry condition with TS $\%$ of 20.9 and 20.4 for M1 and M2 respectively (table 3$)$. Using thermophilic $\left(55^{\circ} \mathrm{C}\right)$ condition of incubation as a new technique. Dry anaerobic digestion (water content $75 \%$ ) has some benefits of using smaller reactor size and smaller wastewater treatment facility than those of conventional processes (Abouelenien et al., 2009). Rice straw as a carbon rich substrate In contrast to organic nitrogen rich substrates, with which anaerobic digestion in dry condition proceeded at a lower efficiency due to the accumulation of ammonia (Koster and Lettinga 1984; Heinrichs et al., 1990; Krylova et al., 1997; Sung and Liu 2003), and will not show this problem. Temperature played an important role in determining both biogas yield and kinetics (Contreras et al., 2012). Thermophilic temperature will enhance the degradation of rice straw and improve the anaerobic digestion by 
methanogenic bacteria in the sludge (Buhr and Andrews 1977).

The $\mathrm{C} / \mathrm{N}$ ratio of rice straw is very high which is not appropriate for anaerobic bacteria, (Forster-Carneiro et al., 2007). To adjust the $\mathrm{C} / \mathrm{N}$ to the preferred range 15-30 ( $\mathrm{Li}$ et al., 2013), sludge was added to rice straw. In the current study TS\% of both mixtures were decreased by anaerobic digestion as illustrated in table 5. Also reduction in VS was observed in both mixtures after first and second batch.

VFA was measured at the initial and final of first and second batch, only acetate and propionate were detected in trace amounts. Acetate was detected in trace amounts not exceed the range of 0.74$0.93 \mathrm{mM} / \mathrm{kg}$-mixture. And this meant that all amounts of acetate produced were rapidly converted to methane and no acetate accumulation was observed. In all mixtures better performance of anaerobic digestion was observed in $2^{\text {nd }}$ batch than the first one (table 5 and fig 2 a,b). This could be explained through the process of acclimatization which occurred to methanogens in seed sludge for the degradation of rice straw (Demirci and Demirer, 2004).

The decreased TS $\%$ and consequently VS $\%$ of M1 and M2 in 1st and 2nd batch (Table 5) indicated the degradation of rice straw organic matter to methane during the anaerobic digestion under different experimental conditions in the current study. This results were in compatible with that obtained by Contreras et al. (2012) and Cunderand Haladova (2014).

The Methane potential (MP) has been widely used to determine the methane yield of organic substrates in specific conditions (Owen et al., 1979; Nallathambi, 1997; 2004; Luna-delRisco et al., 2011). The methane potential, however, of untreated rice straw is on the lower end when compared to other agricultural biomasses and agro-industrial by-products. Several studies have been conducted to determine the ultimate methane yield of rice straw with various inocula, and the results range from 92 to $404 \mathrm{~L} / \mathrm{kg}$ of VS added at ambient and mesophilic temperatures, (Dinuccio et al., 2010; Lei et al., 2010 and Lianhua et al., 2010). There is considerable variation in methane yield of straw depending on the type of pretreatment, if any, and the digestion conditions (Moller et al., 2004). The values of potential methane production from grinded, wet milled, and glucose as reference was 234, 230, and $338 \mathrm{l} / \mathrm{kg}$ vs respectively which located in the range that mentioned in the previous studies (Table. $6)$.

\section{CONCLUSION}

One of the major challenges with the digestion of rice straw is the lignocellulosic structure that makes bacterial decomposition difficult. Wet milling was seemed to enhance methane production from rice straw with maximum production of $1493.98 \mathrm{ml} / \mathrm{g}$-vs compared with $387.7 \mathrm{ml} / \mathrm{g}$-vs from grinded one. Methane percentage was ranged from 48 to $55 \%$. Acetate production was low and ranged from 0.74 to $0.93 \mathrm{mM} / \mathrm{kg}$ mixture which was meant success of methane production. Thermophilic condition was used at $55^{\circ} \mathrm{C}$ which in contrast to previous study enhance the degradation. Methane potential from grinded, wet milled, and glucose as reference was 234 , 230 , and $3381 / \mathrm{kg}$ vs respectively.

\section{REFERENCES}

Abouelenien, F.; Kitamura, Y.; Nishio, N. and Nakashimada, Y. (2009): Dry anaerobic ammonia-methane production from chicken manure. Appl Microbiol Biotechnol; 82: 757764.

Abouelenien, F.; Fujiwara, W.; Namba, Y.; Kosseva, M.; Nishio, N. and Nakashimada, Y. (2010): Improved methane fermentation of chicken manure via ammonia removal by biogas recycle. Bioresource Technology, 101, 63686373.

Akmal, T.; Fahmy, M. and El Kadi, A. (2011): Rice straw based cement brick microclimatic thermal impact assessement in Cairo, Egypt. World renewable energy congress.

Alvira, P.; Tomas-Pejo, M.; Ballesteros, M. and Negro, M.J. (2010): Pretreatment technologies for an efficient bioethanol production process based on enzymatic hydrolysis. Areview. Bioresource. Technology. 101: 4851-4861.

Angelidaki, I. and Sanders, W. (2004): Assessment of the anaerobic biodegradability of macropollutants Environmental Science and Bio/Technology 3: 117-129.

APHA (1998): Standard methods for the examination of water and wastewater, 20th ed. APHA, AWWA, WEF, Washington, DC.

Buhr, H.O. and Andrews, J.F. (1977): The thermophilic anaerobic digestion process. water. Res., 11: 129-143.

Chandra, R.; Takeuchi, H. and Hasegawa, T. (2012): Methane production from lignocellulosic agricultural crop wastes: A review in context to second generation of biofuel production. Renewable and sustainable Energy Reviews. 16(3): 1462-1476.

Chen, J. and Lei, Z. (2008): Preliminary study on acclimation for anaerobic digestion of rice straw. Journal of Fudan University (Natural Sciences).47(5): 652-658.

Contreras, L.M.; Schelle, C.; Sebrango, R. and Pereda, I. (2012): Methane potential and biodegradability of rice straw, rice husk and rice residues from the drying process. Water 
Sci. Technol.; 65(6): 1142-9; DOI: 10.2166/wst. 2012.951.

Cundr, O. and Haladová, D. (2014): Biogas yield from anaerobic batch co-digestion of Rice Straw and zebu dung. Scientia agriculturae bohemica, 45 (2): 98-103.

Demirci, GG. and Demirer, GN. (2004): Effect of initial COD concentration, nutrient addition, temperature and microbial acclimation on anaerobic treatability of broiler and cattle manure. Biores Technol 93: 109-117.

Demirel, B. and Scherer, P. (2011): Trace element requirements of agricultural biogas digesters during biological conversion of renewable biomass to methane. Biomass and Bioenergy; 35: 992.

Dinuccio, E.; Balsari, P.; Gioelli, F. and Menardo, S. (2010): Evaluation of the biogas productivity potential of some Italian agro-industrial biomasses. Bioresour Technol; 101: 3780.

El Saidy, N. (2011): Black cloud as an environmental pollutant and its impact on animal and poultry health. PhD. Thesis. Fac. Vet. Med. Kafrelshiekh University.

El-Shinnawi, MM.; Alaa El-Din, MN.; El-Shimi, SA. and Badawi, MA. (1989): Biogas production from crop residues and aquatic weeds. Resource Conservation and Recycling; 3: 33.

Endo, T.; Tanaka, N.; Yamasaki, R.; Teramoto, Y. and Lee, S.H. (2008): Wet mechanochemical treatment for enzymatic saccharification of wood. In: 15th Annual Meeting of the Cellulose Society. Vols. 10-11, Koyoto, Japan: 117-118.

FAOSTAT, (2011): Global rice production by year, Food and Agriculture Organization of the United Nations. Retrieved on 11 th October 2011 from http://faostat.fao.Org.

Feng, L.; Li, Y.; Chen, C.; Liu, X.; Xiao, X.; Ma, X.; Zhang, R.; He, Y. and Liu, G. (2013): Biochemical methane potential (BMP) of vinger residue and the influence of feed to inoculum ratios inoculum ratios on biogas production. Bioresearches. 8 (2): 2487-2498.

Forster-Carneiro, T.; Perez, M. and Romero, L.I. (2007): Composting potential of different inoculum sources in the modified SEBAC system treatment of municipal solid wastes. Bioresour. Technol. 98, 3354-3366.

Ghosh A,B.C.B. (1999): Biomethanation of white rotted and brown rotted rice straw. Bioprocess Engineering; 20:297.

Heinrichs, D.M.; Poggi-Varaldo, H.M. and Olieskewicz, J.A. (1990): Effect ofammonia on anaerobic digestion of simple organic substrates. J. Environ Eng 116: 698-710.

Hideno, A.; Inoue, H.; Tsukahara, K.; Fujimoto, S.; Minow, T.; Inoue, S.; Endo, T. and Sawayama, S. (2009): Wet disk milling pretreatment without sulfuric acud for enzymatic hydrolysis of rice straw. Bioresour. Technol. 100: 2706-
2711.

Kadam, K.L.; Forrest, L.H. and Jacobson, W.A. (2000): Rice straw as a lignocellulosic resource: collection, processing, transportation and environmental aspects. Biomass and Bioenergy. 18(5): 369-389.

Kim Oanh, N.T.; Nghiem, L.H. and Yin, L.P. (2002): Emission of polycyclic aromatic hydrocarbon, toxicity and mutagenicity from domestic cooking using sawdust briquettes, wood and kerosene. Environmental Science and Technology. 36: 833-839.

Kim Oanh, N.T.; Albina, D.O.; Li, P. and Wang, X.K. (2005): Emission of particulate matter and Polycyclic aromatic hydrocarbons from select cook stove fuel systems in Asia. Biomass and Bioenergy. 28: 579-590.

Koster, J.W. and Lettinga, G. (1984): The influence of ammonium-nitrogen on the specific activity of pelletized methanogenic sludge. Agricultural Wastes 9: 205-16.

Krylova, N.I.; Khabiboulline, R.E.; Naumova, R.P. and Nagel, M.A. (1997): The influence of ammonium and methods for removal during the anaerobic treatment of poultry manure. $\mathrm{J}$. Chem. Tech. Biotechnol 70: 99-105.

Lei, Z.; Chen, J.; Zhang, Z. and Sugiura, N. (2010): Methane production from rice straw with acclimated anaerobic sludge: effect of phosphate supplementation. Bioresour Technol; 101:4343.

Li, Y.; Zhang, R.; Chen, C.; Liu, G.; He, Y. and Liu, X. (2013): Biogas production from codigestion of corn stover and chicken manure under anaerobic wet, hemi-solid, and solid state conditions. Bioresour. Technol. 149, 406-412.

Lianhua, L.; Dong, L.; Yongming, S.; Longlong, M.; Zhenhong, Y. and Xiaoying, K. (2010): Effect of temperature and solid concentration on anaerobic digestion of rice straw in South China. Int. J. of Hydrogen Energy; 35: 7261.

Luna-delRisco, M.; Normak, A. and Orupõld, K. (2011): Biochemical methane potential of different organic wastes and energy crops from Estonia. Agronomy Research 9 (1-2), 331-342.

Magbanua, B.S.; Adams, T.T. and Johnston, P. (2001): Anaerobic co-digestion of hog and poultry waste. Bioresource Technology, 76, 165-168.

Mansaray, K.G.; Ghaly, A.E.; Al Taweel, A.M.; Hamdullahpur, F. and Ugursal, V.I. (1999): Air gasification of rice husk in a dual distributor type fluidized bed gasifier. Biomass and Bioenergy. 17(4): 315-332.

Mansour, A.; Srebric, J. and Burley, B.J. (2007): Development of straw cement composite sustainable building material for low cost housing in Egypt. Journal of Applied Science Research. 3(11): 1571-1580.

Moller, H.B.; Sommera, S.G. and Ahring, B.K. (2004): Methane productivity of manure, straw and 
solid fractions of manure. Biomass and Bioenergy. 26:485.

Mosier, N.; Wyman, C.E.; Dale, B.E.; Elander, R.T.; Lee, Y.Y.; Holtzapple, M. and Ladisch, M. (2005): Features of promising technologies for pretreatment of lignocellulose biomass. Biores. Technol. 96: 673-686.

Moussa, M.l. and Abdelkhalek, A.M. (2007): Meterological analysis for black cloud (Episodes) formation and its monotoring by remote sensing. Journal of applied Science Research. 3 (2): 147-154.

Mussoline, W.; Esposito, G.; Lens, P.; Spagni, A. and Giordano, A. (2013): Enhanced methane production from rice straw co-digested with anaerobic sludge from pulp and paper mill treatment process. Bioresour Technol; 148: 135.

Mussoline, W.; Esposito, G.; Lens, P.; Garuti, G. and Giordano, A. (2012): Design considerations for a farm-scale biogas plant based on pilotscale anaerobic digesters loaded with rice straw and piggery wastewater. Biomass and Bioenergy; 46: 469.

Nallathambi, G.V. (1997): Anaerobic digestión of biomass for methane production: A review. Biomass Bioenerg, 13, 83-114.

Nallathambi, G.V. (2004): Biochemical methane potential of fruits and vegetable solid waste feedstocks. Biomass Bioenerg, 26, 389-399

Nishio, N. and Nakashimada, Y. (2007): Recent development of anaerobic digestion processes for energy recovery from wastes, J. Biosci. Bioeng., 103, 105-112.

Niu, H.; He, Y.; Desideri, U.; Zhang, P.; Qin, H. and Wang, S. (2013): Rural household energy consumption and its implications for ecoenvironments in NW China: A case study.
Renewable Energy; http://dx.doi.org/10.1016/j. renene.2013.07.045.

Ondrej, C. and Dagmar, H. (2103): Biogas yield from anaerobic batch Co-digestion of rice husk and Zebu Dung. Agriculture tropica et subtropica, 46/4:118-122.

Owen, W.F.; Stuckey, D.C.; Healy, J.B.; Young, L.Y. and McCarty, P.L. (1979): Bioassay for monitoring biochemical methane potential and anaerobic toxicity. Water Research, 13, 485-492.

Sreepada, H. and Vijayalaxmi, H. (2013): Assessment of global rice production and export opportunity for economic development in Ethiopia. International Journal of Science and research.2 (6): 2319-7067.

Sung, S. and Liu, T. (2003): Ammonia inhibition on thermophilic anaerobic digestion. Chemosphere 53:43-52.

Sun, Y. and Cheng, J. (2002): Hydrolysis of lugnocellulose materials for ethanol production. areview. Bioresource technology. 83:1-11.

Sun, G.; Wu, Y.; Sha, S. and Liu, K. (1987): Dry digestion of crop wastes: studies on dry anaerobic digestion with agricultural wastes. Biological Wastes; 20: 291.

Van Nguu, N. (2000): FAO Rice information. Volume 2. Chapter I.

Yanagida, T.; Fujimito, S.; Hindo, A.; Inoue, H.; Tsukahara, K.; Sawayama, S. and Minowa, T. (2009): Energy and economic evaluation for ethanol production of non sulfuric acid pretreatment method from rice straw.J.Jpn. Soc. Energy Resour. 30:8-12.

Zhang, R. and Zhang, Z. (1999): Biogasification of rice straw with an anaerobic-phased solids digester system. Bioresou. Technol. 65:235.

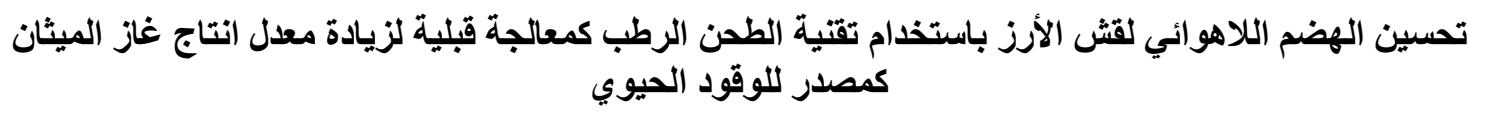

نغم الصعيلى ، فاطمه /بو العينين ، بيوتاكا ناكاشييادا

E-mail: nagham.elsaidy@yahoo.com Assiut University web-site: www.aun.edu.eg

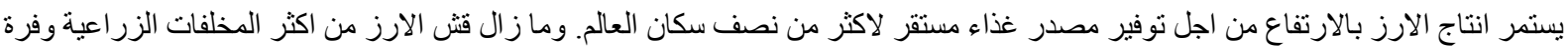

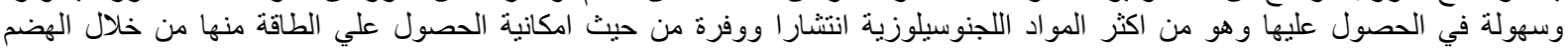

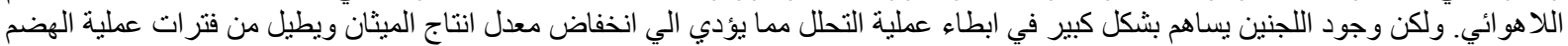

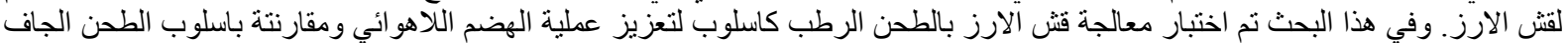

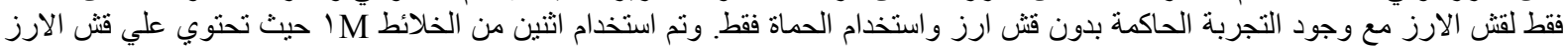

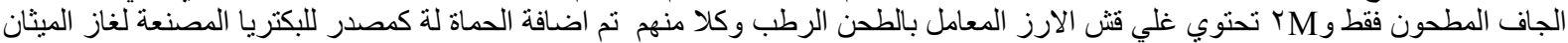

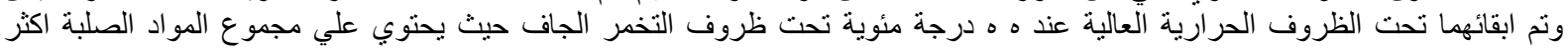

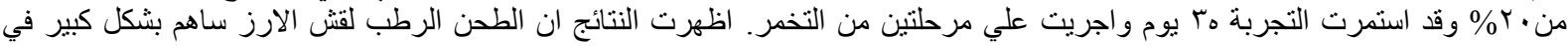

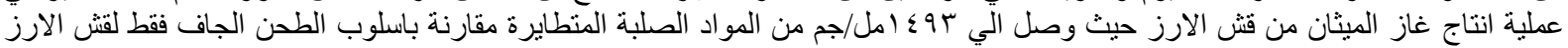

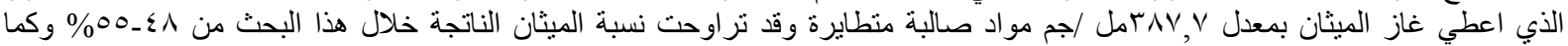

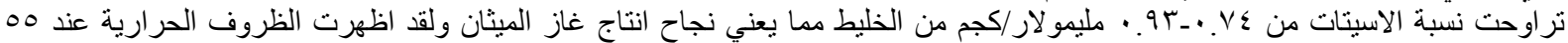

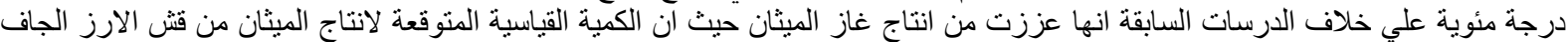

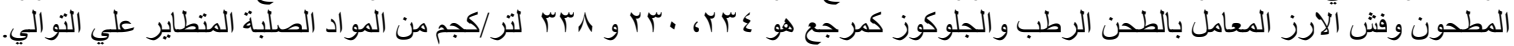

